Dept. of Food Hygiene, Port-Said Lab.,

Animal Health Research Institute, Dokki, Giza, Egypt.

\title{
ASSESSMENT OF NITRITE AND SORBIC ACID SALTS LEVEL IN SOME MEAT PRODUCTS AND THEIR PUBLIC HEALTH SIGNIFICANCE
}

(With 8 Tables and One Figure)

By

\section{H. EL-S.M. FARAG and NOHA R.M. ABD-EL-FATAH* \\ *Dept. of Food Hygiene, Animal Health Research Institute, \\ Dokki, Giza, Egypt. \\ (Received at 8/1/2011)

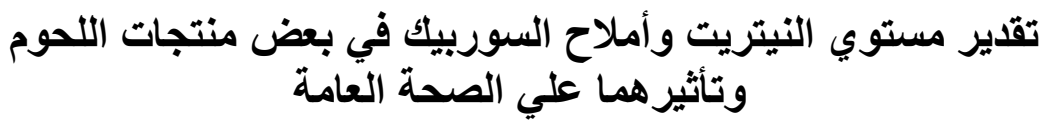

$$
\text { حسن السبإ محد فرج ، نهي رشدي محد عبل الفتاح }
$$

في در اسة لتقدير مستوي النترات و النيتريت وأم لاح السوربيك في بعض منتجات اللحوم تم

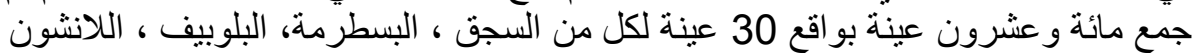

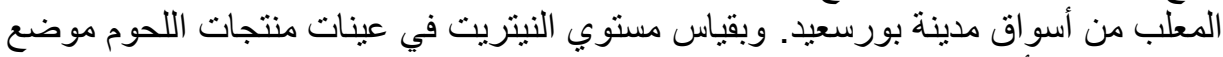

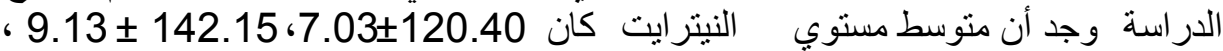

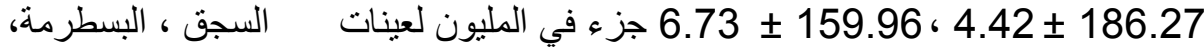

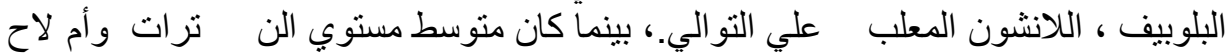

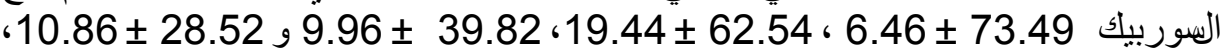

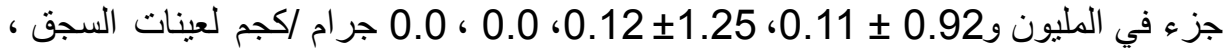

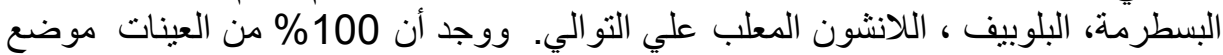

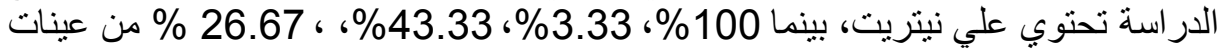

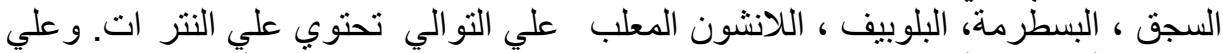
الجانب الأخر وجد أن 100\% من عينات السجق و البسطرمة تحتوي علي أمّلاح السوربيك

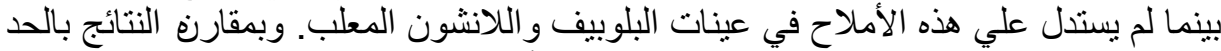

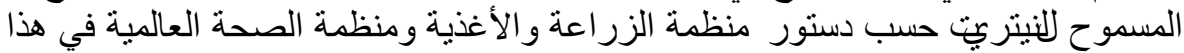
الشأن وجد أن 3 (10\%) (23.33\%) ، 7 (13.33\%) من عينات البسطرمة، البلوبيف

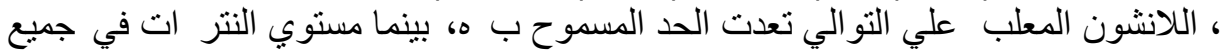

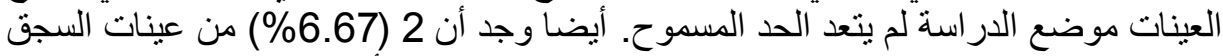

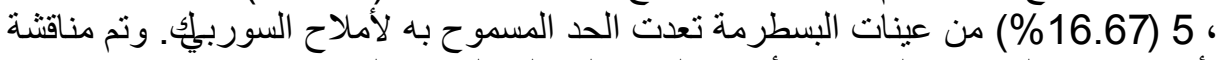
تأثير مستوي النترات و النيتريت و أملاح السوربيك على علي الصدحة العامة. 
One hundred twenty samples of some meat products (30 each of sausage, pastrami, corned beef and canned luncheon beef) were randomly purchased from Port-Said markets. The samples were examined for assessment the levels of nitrite, nitrate and sorbic acid salts. The obtained results revealed that the mean values of nitrite level in the examined meat products were $120.40 \pm 7.03,142.15 \pm 9.13$, $186.27 \pm 4.42$ and $159.96 \pm 6.73 \mathrm{ppm}$ for sausage, pastrami, corned beef and canned luncheon beef respectively. While that of nitrate and sorbic acid salts were $73.49 \pm 6.46,62.54 \pm 19.44,39.82 \pm 9.96$ and 28.52 $\pm 10.86 \mathrm{ppm}$ and $0.92 \pm 0.11,1.25 \pm 0.12,0.00$ and $0.00 \mathrm{~g} / \mathrm{kg}$ for sausage, pastrami, corned beef and canned luncheon beef respectively. For all samples nitrite was detected in $100 \%$ of the examined samples, while nitrate was detected in $100,3.33,43.33$ and $26.67 \%$ of the sausage, pastrami, corned beef and canned luncheon beef samples respectively. On the other hand sorbic acid salts was detected in $100 \%$ of sausage and pastrami samples and could not be detected in the corned beef and canned luncheon beef samples. For all specimens 3 (10\%), 7 (23.33\%) and $4(13.33 \%)$ of pastrami, corned beef and canned luncheon beef samples exceeded the permissible limits of nitrite established by JECFA "FAO/WHO" (1974) respectively, while nitrate not exceed the permissible limits. In case of sorbic acid salts $2(6.67 \%)$ of sausage and $5(16.67 \%)$ of pastrami exceeded the permissible limits of sorbic acid salts. The effects of nitrite, nitrate and sorbic acid salts levels on public health significance were discussed.

Key words: Meat products, preservatives, nitrate, nitrite, sorbic acid.

\section{INTRODUCTION}

Meat and meat products are important component of diet for a large majority of people and considered the vital part of any balanced and nutritious diet. They have a highly nutritive value and palatability thus considered a highly perishable foods and an excellent environmental source for microbial growth (Garcia et al., 1995; Kalalou et al., 2004).

The potential of food contamination and spoilage makes it necessary to add preservatives to foods (Lindsay, 1985). Food preservation has become an increasingly important practice in modern food technology with the increase in the processed and convenience foods (Saad et al., 2005). These preservatives are added to stop or delay the nutritional losses and meat spoilage due to microbiological, 
enzymatic or chemical changes of foods and to prolong shelf life and quality of food (Mota et al., 2003).

The most commonly used preservatives in meat processing are nitrite, nitrate and sorbic acid (Mihyar et al., 1999). Sodium and potassium salts of nitrite and nitrate are widely used as preservatives in meat processing. The nitrite is either added as salts or produced from nitrate by microbial reduction. Nitrite and/or nitrate plays a crucial role in the curing process, which results in the typical sensory properties and an appealing pinkish reddish color to the meat products that is well know by consumers consequently prevent meat products from turning brown or grey colored. (Dahle, 1979; Noel et al., 1990; Hyytia et al., 1997). The coloring of the processed meat results from the conversion of nitrate to nitrite by chemical reaction that reacts with the myoglobin to form a bright red nitrosomyoglobin. This bright red color is converted into permanent pink pigment nitrosohemochrome under effect of cooking (Hyytia et al., 1997). Generally, nitrite has antimicrobial properties that prevent pathogenic and non-pathogenic bacteria. Nitrite control or prevent the growth of spores particularly of Clostridium botulinum, these spores are a real concern in the food industry because they can survive normal heat processing under right conditions, they can produce vegetative cells which resulted in food poisoning by their lethal toxin (Olsman, 1977; Roberts and Ingram, 1977; Noel et al., 1990; Hyytia et al., 1997). Besides the coloring and antimicrobial effect of nitrite and nitrate, they have antioxidant properties and can preserve the taste and flavoring and prevent warmed over (undesirable flavors), off odors and rancidity of several meat and meat products during their storage (AMI, 1978; Dahle, 1979; Honikel, 2008).

The other most common used food preservatives were sorbic acid and its water-soluble salts specially potassium sorbate. The microbiological safety of food products was best ensured by addition of potassium sorbates (Shahidi et al., 1988; Ferrand et al., 2000 a). Sorbates are naturally occurring unsaturated fatty acid and considered the best antibacterials agents because their broad spectrum of action. They effectively inhibit certain bacteria and food born yeast and mold species (Sofos and Busta, 1993). The inhibitory effect of sorbates on microorganisms may be lethal or static. The mechanism by which sorbates inhibits microbial growth may be due to its effect on enzymes such as dehydrogenase involved in fatty acid oxidation and sulfhdryl enzyme such as succinic dehydrogenase and yeast alcohol dehydrogenase (Davidson and Juneja, 1990; Sofos and Busta, 1993). 
Many epidemiological studies have showed that diets plays a substantial role in the etiology of many forms of cancer and it has been estimated that as much as $40-60 \%$ of cancer cases may be attributed to factors associated with diets (Miller, 1985; Twombly, 1995). Thus, a specific attention has been focused on the possible role of nitrite and nitrate, in cancer (Jakszyn and Gonzalez, 2006). The potential health dangerous of nitrite referred to its ability to reacts with secondary amines and amides present in the meat products under acidic condition to form nitrosamine. This compound is strong mutagens and powerful carcinogenic in animals and potential in humans causing cancer in certain body organs and tissues e.g. stomach, urinary bladder and others organs (Lijinsky and Kovatch, 1982; Mirvish, 1995). Nitrosamine may be ingested directly with cured meat or may be formed in vivo in the stomach (Howe et al., 1986; Nijinsky, 1999). Ingested nitrates can be reduced to nitrite in the saliva and thus these compounds are considered as potential precursor of endogenously formed nitrosamine (Shapiro et al., 1991; Grosse et al., 2006). Nitrites also have a vasodilator effect cause intravascular hemolysis in human specially that with glucose-6phosphate dehydrogenase deficiency (Chan, 1996), headaches (Henderson and Raskins, 1972), hypotension, abdominal pain, acidosis (Gosselin et al., 1984) and linked with triggering migraines (FDA, 1998). In infants, epidemiological evidence showed a relationship between consumption of cured meats and incidence of childhood leukemia, brain tumors, methaemoglobinaemia (blue baby syndrome) and cyanosis due to the reaction of nitrite with hemoglobin in the red blood cells. Some of these signs may appear also in young children and elder person (Sen and Baddoo, 1997).

On the other hand, sorbates are low or non-toxic even in large quantities (Shahidi et al., 1988; Ferrand et al., 2000 a) and considered the lowest allergenic potential of all food preservatives. They do not accumulate in the body and being rapidly metabolized by pathway similar to those of other fatty acids through $B$-oxidation to form $\mathrm{CO}_{2}$ and $\mathrm{H}_{2} \mathrm{O}$ (Lindsay, 1996; Walker, 1990). Sorbic acid act as a nucleophile and form complex with amino compounds under normal food processing conditions with the resulting adducts being devoid of genotoxic activity (Ferrand et al., 2000 b). In human, few cases of idiosyncratic intolerance to sorbic acid have been reported such as non-immunological contact urticaria and pseudo-allergy (Safford et al., 1990; Walker, 1990)

Therefore, the objective of the present study aimed to investigate the level of nitrite, nitrate and sorbic acid salts in sausage, pastrami, corned beef and canned luncheon beef that mostly consumed by people 
to evaluate the overall safety of these preservatives in such meat products.

\section{MATERIALS and METHODS}

\section{1: Samples collection:}

A total of 120 random samples of some meat products (30 each of sausage, pastrami, corned beef and canned luncheon beef) were purchased from Port-Said markets. Each individual sample was placed separately into sealed plastic bags, thoroughly identified and delivered to the laboratory. All specimens were processed for assessment the levels of the nitrite, nitrate and sorbic acid and its salts.

\section{2: Chemical examination:}

\section{2-1: Preparation of the samples:}

All specimens of sausage, pastrami, and the entire contents of the corned beef and canned luncheon beef meat, were separately passed rapidly three times through food chopper with plate opening equal to $1 / 8^{\text {th }}$ inch $(3 \mathrm{~mm})$, mixed thoroughly after each grinding to obtain a uniform mass and finally began all determinations promptly. The homogenate sample was transferred to a wide mouth glass or other suitable container with an airtight stopper. The analysis was carried out as soon as possible, if any delay, the sample was chilled to inhibit the decomposition (A.O.A.C., 2000).

\section{2-2: Determination of nitrite and nitrate levels:}

\section{2-2-1: Reagents:}

All reagents used were of analytical grade purchased from Merck (Merck, Darmstadt, Germany) and Sigma-Aldrich (Sigma, St. Louis, MO). Nitrite standard were obtained from Sigma-Aldrich.

\section{2-2-2: Sample extraction:}

In $50 \mathrm{ml}$ beaker, $5 \mathrm{gm}$ of the prepared sample were weighed to which about $40 \mathrm{ml}$ of heated water (at $80^{\circ} \mathrm{C}$ ) were added and mixed thoroughly with glass rod then transferred to $500 \mathrm{ml}$ volumetric flask. Beaker and glass rod were thoroughly washed with successive portions of hot water (at $80^{\circ} \mathrm{C}$ ) and all washings water were added to flask. Enough hot water was added to bring volume to about $300 \mathrm{ml}$. The flask was put in steam bath and let stand for 2 hours with shaking occasionally. The samples were cooled to room temperature, diluted to volume with water and remixed then filtered (by free nitrite and nitrate filter paper); if turbidity remained after filtration, centrifuging will usually clear the solution (I.S.O., 1975; A.O.A.C., 2000).

\section{2-2-3: Standard curve of nitrite:}


In $50 \mathrm{ml}$ volumetric flask, $2.5 \mathrm{ml}$ of sulphanilamide solution $(0.5$ gm of sulphanilamide were dissolved in $150 \mathrm{ml}$ of $15 \%$ acetic acid (v/v) then filtered "by free nitrite and nitrate filter paper" and stored in a glass stoppered brown bottle) were added and thoroughly mixed with aliquot containing 5-50 $\mu \mathrm{g} \mathrm{NaNO}_{2}$ (was prepared by added 10, 20, 30, $40 \mathrm{ml}$ of nitrite working solution). After 5 minutes, $2.5 \mathrm{ml}$ NED reagent $(0.2 \mathrm{gm}$ $\mathrm{N}$ - "1 Napthyl" ethylenediamine dihydrochloride were dissolved in 150 $\mathrm{ml}$ of $15 \%$ (v/v) acetic acid), were added and diluted to volume with mixing and let color developed 15 minutes. A portion of the solution was transferred to photometer cell and determined absorbance at $540 \mathrm{~nm}$ against blank. Standard curve is straight line up to 1 ppm $\mathrm{Na} \mathrm{NO}_{2}$ in final solution according to A.O.A.C. (2000).

Standard Calibration Curve for Nitrite (5-50 $\mu \mathrm{g})$

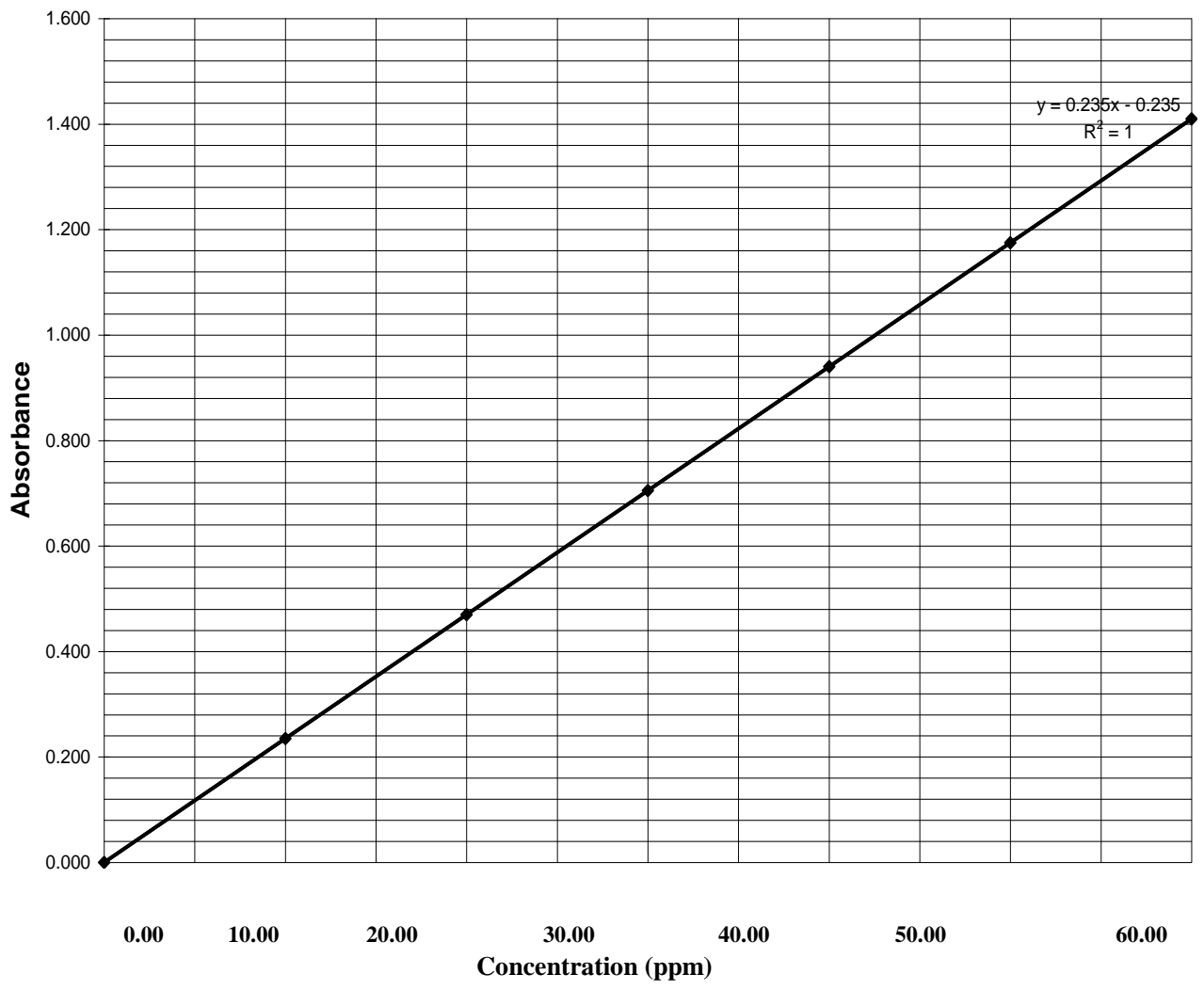

\section{2-2-4: Reduction of nitrate to nitrite:}

The nitrate residue in the sample aliquot was reduced to nitrite by acid reduction technique according to Narayana and Sunil (2009). $5 \mathrm{ml}$ 
concentrated $\mathrm{HCl}$ and $2 \mathrm{ml}$ of $\mathrm{Zn} / \mathrm{NaCl}$ granular mixture were added to $10 \mathrm{ml}$ of the sample aliquot. The mixture was allowed to stand for 30 minutes with occasionally stirring to form nitrite and then filtered the solution to $100 \mathrm{ml}$ volumetric flask using Whitman filter paper No. 41 . The filtrate was diluted up to the mark and the reduced nitrate levels was assessed and calculated according to A.O.A.C. (2000).

\section{2-2-5: Assessment of the sample for nitrate and nitrite levels:}

In $50 \mathrm{ml}$ volumetric flask, $2.5 \mathrm{ml}$ of sulphanilamide solution were added and mixed with $45 \mathrm{ml}$ of the sample filtrate. After 5 minutes, $2.5 \mathrm{ml}$ NED reagent were added and diluted to volume with mixing and let color develop 15 minutes. A portion of sample solution was transferred to photometer cell and determined absorbance at $540 \mathrm{~nm}$ against blank of $45 \mathrm{ml}$ water and $2.5 \mathrm{ml}$ sulphanilamide reagent and $2.5 \mathrm{ml}$ of NED reagent. Nitrite concentrations in the samples were determined by comparison with standard curve. All the estimations were carried out in duplicate for each of reduced and non reduced aliquot according to A.O.A.C. (2000).

2-2-6: Calculation (A.O.A.C., 2000):

Nitrite content (expressed as $\mathrm{NaCO}_{2}$ )

"Without reduced nitrate $\mathrm{NaCO}_{3} "$

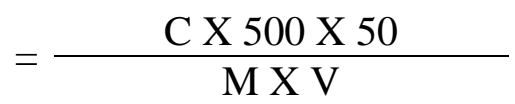

Nitrite content (expressed as $\mathrm{NaCO}_{2}$ )

"With reduced nitrate $\mathrm{NaCO}_{3}$ "

$=\frac{\mathrm{CX} 500 \times 50 \times 10}{\mathrm{M} \times \mathrm{V}}$

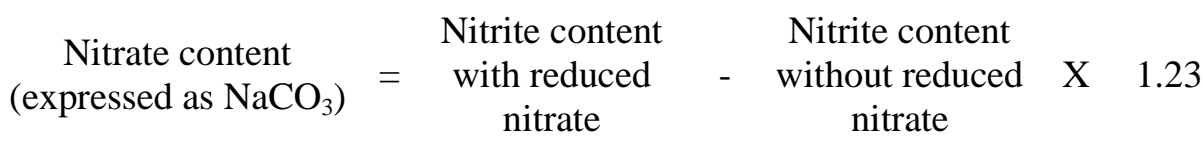

$\mathrm{C}=$ Concentration of sodium nitrite in $\mu \mathrm{g} / \mathrm{ml}$ read from the calibration curve that corresponds with the absorption of the solution prepared from the sample.

$\mathrm{M}=$ Mass in gm of sample taken.

$\mathrm{V}=$ Volume in $\mathrm{ml}$ of aliquot portion of filtrate taken for test.

$1.23=$ factor to convert nitrite to nitrate

\section{2-3: Determination of Sorbic acid salts:}

\section{2-3-1: Reagent:}


All reagents used were of analytical grade purchased from Merck (Merck, Darmstadt, Germany) and Sigma-Aldrich (Sigma, St. Louis, MO). Sorbic acids standard were obtained from Sigma-Aldrich.

\section{2-3-2: Sample extraction (oxidation methods):}

In one liter steam distillation flask, $50 \mathrm{gm}$ of the prepared sample were weighed and $100 \mathrm{gm}$ of magnesium sulphate hexahydrate and 100 $\mathrm{ml} 1 \mathrm{~N}$ sulphuric acid were added. Rapidly the prepared sample (do not heat the distilling flask) was steam distilled and the distillates were received in the receiving flask containing $10 \mathrm{ml}$ of $1 \mathrm{~N} \mathrm{NaOH}$. About 450 $\mathrm{ml}$ of distillate were collected in about 30 minutes, cooled and transferred to a $500 \mathrm{ml}$ volumetric flask. $15 \mathrm{ml} 1 \mathrm{~N}$ sulphuric acid were added to the sample aliquot, then diluted to the volume with water and mixed well.

\section{2-3-3: Standard curve of sorbic:}

In $500 \mathrm{ml}$ volumetric flask, $25 \mathrm{ml}$ of the standard sorbic acid stock solution (1.0 gm of sorbic acid was dissolved in a small volume of $1 \mathrm{~N} \mathrm{NaOH}$ and diluted to 1 liter with water "1 mg/ml") were pipetted and diluted to volume with water $(50 \mu \mathrm{g} / \mathrm{ml})$. Next $0.0,10.0,20.0,50.0$ and $80.0 \mathrm{ml}$ of this solution were pipetted into five $100 \mathrm{ml}$ volumetric flasks and diluted to volume with water (range $0,5,10,25$, and $40 \mu \mathrm{g} / \mathrm{ml}$ respectively). Then $2 \mathrm{ml}$ of each of the working standards and blank were pipetted into 5 test tubes and $2 \mathrm{ml}$ of dichromate solution (freshly prepared solution of equal volumes of $0.3 \mathrm{~N}$ sulphuric acid mixed with a solution of $0.5 \mathrm{gm}$ potassium dichromate in 1 liter of water) were added, followed by heating in a boiling water bath for 5 minutes. After cooling, $2 \mathrm{ml}$ of $0.5 \%$ TBA solution ( $0.5 \mathrm{gm}$ of thiobarbituric acid was dissolve in $25 \mathrm{ml}$ water $+20 \mathrm{ml} 0.5 \mathrm{~N} \mathrm{NaOH}$ then added $11 \mathrm{ml} 1 \mathrm{~N} \mathrm{HCL}$ and diluted to $100 \mathrm{ml}$ with water) were added and heated in a boiling water bath for 10 minutes. The mixture was cooled rapidly, transferred to 50 $\mathrm{ml}$ volumetric flask and diluted to the volume with water. The absorbance of the solution was measured at $532 \mathrm{~nm}$ against blank using $1 \mathrm{~cm}$ cuvette. All the estimations were carried out in duplicate and the mean of the duplicate was taken. Plot absorbance $\mu \mathrm{g}$ sorbic acid for a standard curve ( $\mu \mathrm{g}$ sorbic acid $=0,10,20,50,80$ in $2 \mathrm{ml}$ aliquots) according to FAO (1986).

\section{Standard Calibration Curve for Sorbic Acid (5-50 $\mu \mathrm{g})$}




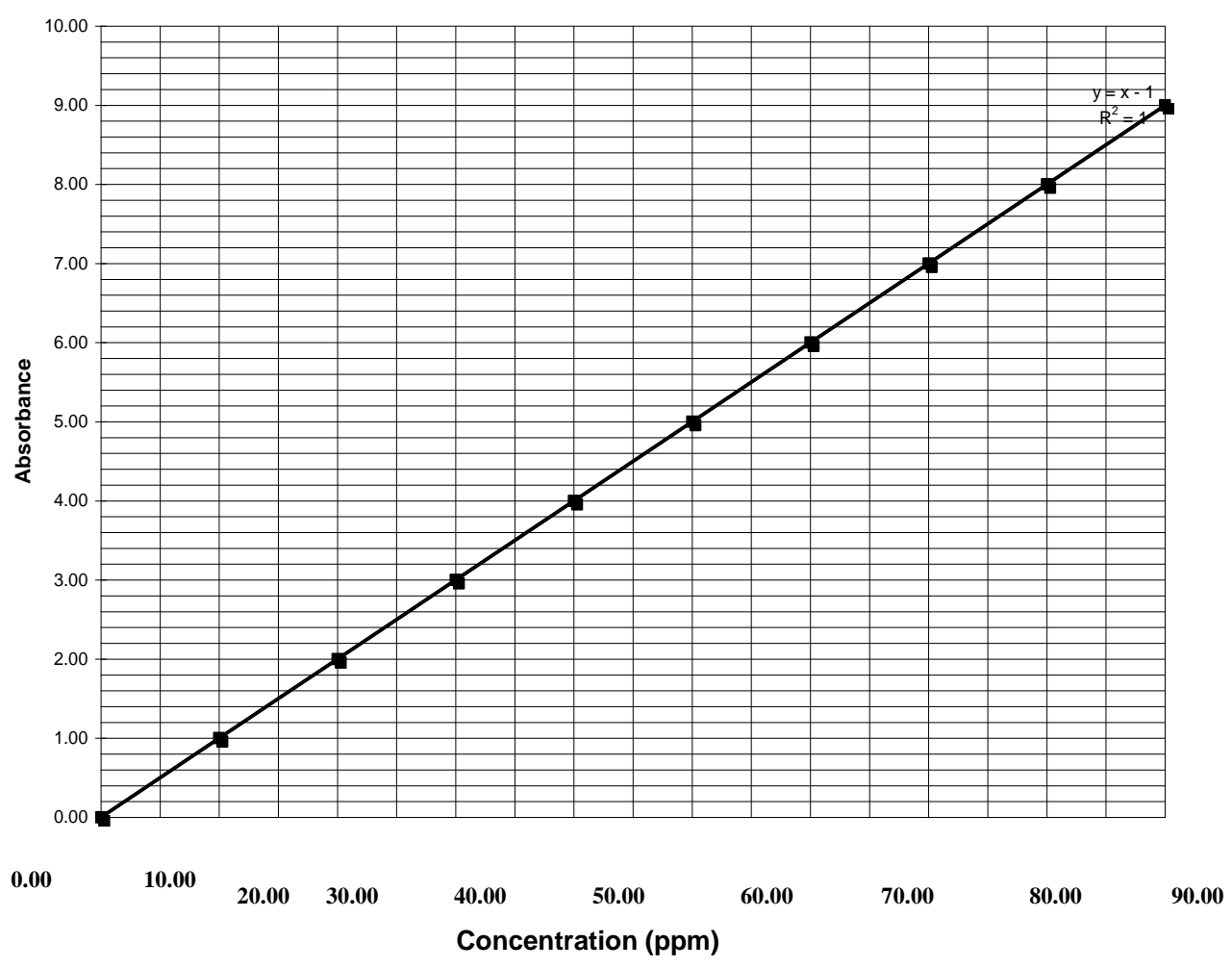

\section{2-3-4: Assessment of the sample levels:}

Two $\mathrm{ml}$ of the aliquots sample were pipetted into a test tube and $2 \mathrm{ml}$ of dichromate solution were added, followed by heating in a boiling water bath for 5 minutes. After cooling $2 \mathrm{ml}$ of $0.5 \%$ TBA solution $(0.5$ gm of thiobarbituric acid was dissolve in $25 \mathrm{ml}$ water $+20 \mathrm{ml} 0.5 \mathrm{~N}$ $\mathrm{NaOH}$ then, added $11 \mathrm{ml} 1 \mathrm{~N} \mathrm{HCl}$ and diluted to $100 \mathrm{ml}$ with water) were added and heated in a boiling water bath for 10 minutes, then cooled rapidly and transferred to $50 \mathrm{ml}$ volumetric flask and diluted to the volume with water. The absorbance of the solution was measured at $532 \mathrm{~nm}$ using $1 \mathrm{~cm}$ cuvette. All the estimations were carried out in duplicate and taken the mean of the duplicate according to FAO (1986). 2-3-5: Calculation (FAO, 1986):

$$
\text { Sorbic acid }(\mathrm{ppm}) \quad=\frac{\mathrm{A}}{\mathrm{S}} \times \frac{500}{2}
$$

Where $\mathrm{A}=\mu \mathrm{g}$ sorbic acid corresponding to sample absorbance, taken from the standard curve $\mathrm{S}=$ sample weight in gm

\section{3: Statistical methods}


Minimum, maximum, mean, standard error and standard deviation of mean as well as frequency distribution were used to describe data. One-Way ANOA test was used to compare the mean of the nitrite, nitrate and sorbic acid salts levels in sausage, pastrami, corned beef and canned luncheon beef. $\mathrm{P}$ value was considered significant if less than 0.05 and 0.01 at $95 \%$ and $99 \%$ respectively. These tests were analyzed using the Statistical Package for Social Scientists (SPSS) for windows 16.0 (SPSS Inc., Chicago, IL, and USA).

\section{RESULTS}

Table 1: Statistical analytical results of the nitrite levels (expressed as ppm of $\mathrm{NaCO}_{2}$ ) recovered from the examined meat products $(n=30$ of each).

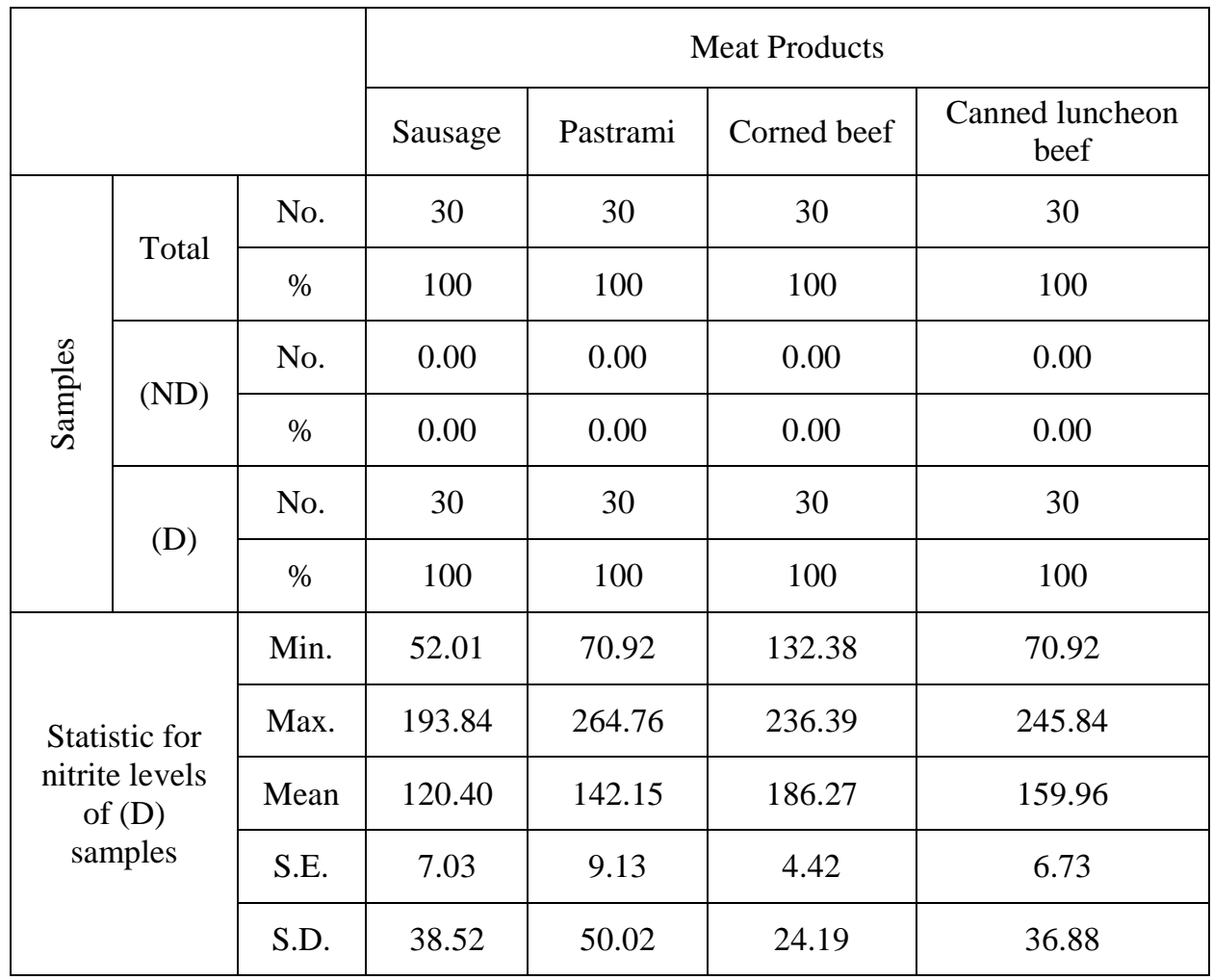

$\mathrm{ND}=$ Non-Detectable. $\quad \mathrm{D}=$ Detectable. Min. $=$ Minimum. $\quad$ Max. $=$ Maximum. $\mathrm{SE}=$ Standard Error $\mathrm{SD}=$ Standard Deviation. 
Table 2: Statistical analytical results of the nitrate levels (expressed as ppm of $\mathrm{NaCO}_{3}$ ) recovered from the examined meat products $(n=30$ of each).

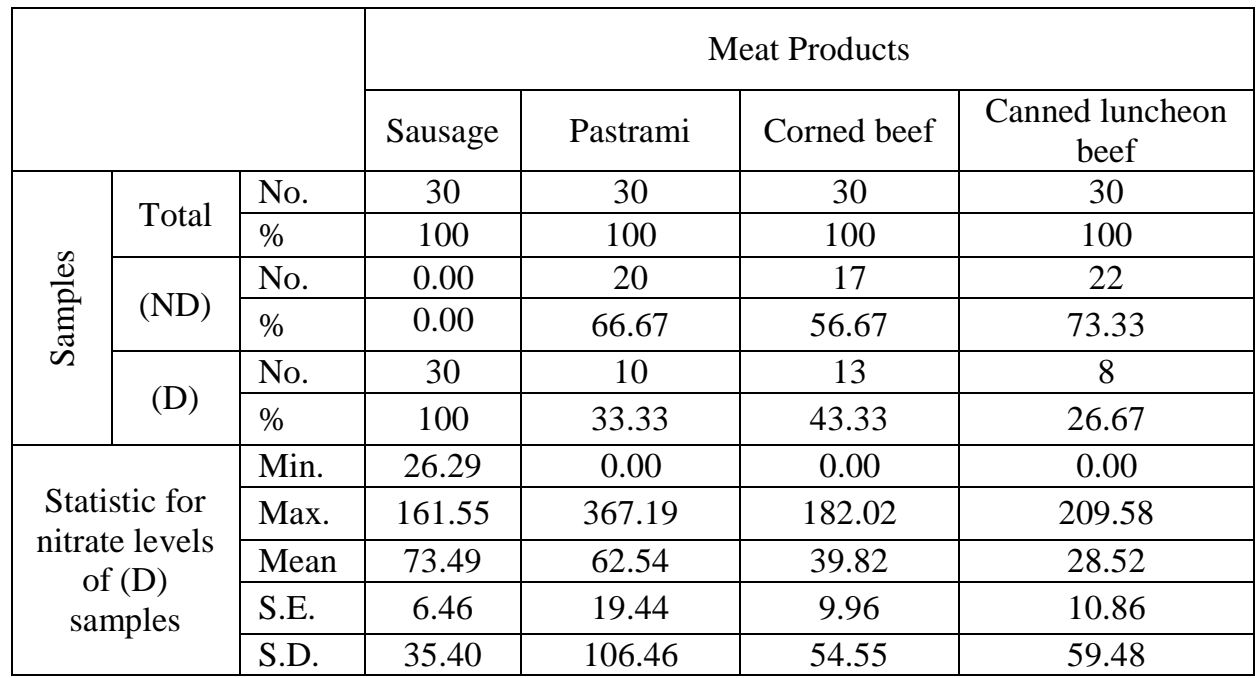

$\mathrm{ND}=$ Non-Detectable. $\mathrm{D}=$ Detectable. Min. $=$ Minimum. $\quad$ Max. $=$ Maximum. $\mathrm{SE}=$ Standard Error $\quad \mathrm{SD}=$ Standard Deviation .

Table 3: Statistical analytical results of the sorbic acid salts levels (expressed as ppm of sorbic acid) recovered from the examined meat products ( $\mathrm{n}=30$ of each).

\begin{tabular}{|c|c|c|c|c|c|c|}
\hline & \multicolumn{4}{|c|}{ Meat Products } \\
\hline & & & Sausage & Pastrami & Corned beef & $\begin{array}{l}\text { Canned luncheon } \\
\text { beef }\end{array}$ \\
\hline \multirow{6}{*}{ 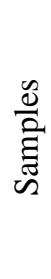 } & \multirow{2}{*}{ Total } & No. & 30 & 30 & 30 & 30 \\
\hline & & $\%$ & 100 & 100 & 100 & 100 \\
\hline & \multirow{2}{*}{ (ND) } & No. & 0.00 & 0.00 & 30 & 30 \\
\hline & & $\%$ & 0.00 & 0.00 & 100 & 100 \\
\hline & \multirow{2}{*}{ (D) } & No. & 30 & 30 & 0.00 & 0.00 \\
\hline & & $\%$ & 100 & 100 & 0.00 & 0.00 \\
\hline \multirow{5}{*}{\multicolumn{2}{|c|}{$\begin{array}{l}\text { Statistic for } \\
\text { sorbic acid } \\
\text { salts levels } \\
\text { of (D) } \\
\text { samples }\end{array}$}} & Min. & 0.10 & 0.15 & 0.00 & 0.00 \\
\hline & & Max. & 2.35 & 2.50 & 0.00 & 0.00 \\
\hline & & Mean & 0.92 & 1.25 & 0.00 & 0.00 \\
\hline & & S.E. & 0.11 & 0.12 & 0.00 & 0.00 \\
\hline & & S.D. & 0.58 & 0.64 & 0.00 & 0.00 \\
\hline
\end{tabular}

$\mathrm{ND}=$ Non-Detectable. $\mathrm{D}=$ Detectable. Min. $=$ Minimum. Max. $=$ Maximum.

$\mathrm{SE}=$ Standard Error $\quad \mathrm{SD}=$ Standard Deviation . 
Table 4: Frequency distribution of the examined meat products based on their nitrite levels ( $\mathrm{n}=30$ of each)

\begin{tabular}{|c|c|c|c|c|c|c|c|c|}
\hline \multirow{2}{*}{$\begin{array}{c}\text { Levels } \\
\text { range }\end{array}$} & \multicolumn{2}{|c|}{ Sausage } & \multicolumn{2}{c|}{ Type of samples } \\
\cline { 2 - 10 } & No. & $\%$ & No. & $\%$ & No. & $\%$ & No. & $\%$ \\
\hline 0 C (ND) & 0 & 0 & 0 & 0 & 0 & 0 & 0 & 0 \\
\hline$>0-50$ & 0 & 0 & 0 & 0 & 0 & 0 & 0 & 0 \\
\hline$>50-100$ & 10 & 33.33 & 9 & 30.00 & 0 & 0 & 1 & 3.33 \\
\hline$>100-150$ & 11 & 36.67 & 6 & 20.00 & 2 & 6.67 & 10 & 33.33 \\
\hline$>150-200$ & 9 & 30.00 & 12 & 40.00 & 21 & 70.00 & 15 & 50.00 \\
\hline$>200-250$ & 0 & 0 & 2 & 6.67 & 7 & 23.33 & 4 & 13.33 \\
\hline$>250-300$ & 0 & 0 & 1 & 3.33 & 0 & 0 & 0 & 0 \\
\hline Total & 30.00 & 100.00 & 30.00 & 100.00 & 30.00 & 100.00 & 30.00 & 100.00 \\
\hline
\end{tabular}

$\mathrm{ND}=$ Non detectable level.

Table 5: Frequency distribution of the examined meat products based on their nitrate levels ( $\mathrm{n}=30$ of each).

\begin{tabular}{|c|c|c|c|c|c|c|c|c|}
\hline \multirow{2}{*}{$\begin{array}{c}\text { Levels } \\
\text { range }\end{array}$} & \multicolumn{9}{|c|}{ Sausage } & \multicolumn{2}{|c|}{ Pastrami } & \multicolumn{2}{c|}{ Corned beef } & \multicolumn{2}{c|}{ Canned luncheon beef } \\
\cline { 2 - 10 } & No. & $\%$ & No. & $\%$ & No. & $\%$ & No. & $\%$ \\
\hline 0 (ND) & 0 & 0 & 20 & 66.67 & 17 & 56.67 & 22 & 73.33 \\
\hline$>0-50$ & 10 & 33.33 & 0 & 0 & 1 & 3.33 & 1 & 3.33 \\
\hline$>50-100$ & 13 & 43.33 & 2 & 6.67 & 7 & 23.33 & 4 & 13.33 \\
\hline$>100-150$ & 6 & 20.00 & 2 & 6.67 & 3 & 10.00 & 0 & 0 \\
\hline$>150-200$ & 1 & 3.33 & 2 & 6.67 & 2 & 6.67 & 2 & 6.67 \\
\hline$>200-250$ & 0 & 0 & 1 & 3.33 & 0 & 0 & 1 & 3.33 \\
\hline$>250-300$ & 0 & 0 & 2 & 6.67 & 0 & 0 & 0 & 0 \\
\hline$>300-350$ & 0 & 0 & 0 & 0 & 0 & 0 & 0 & 0 \\
\hline$>350-400$ & 0 & 0 & 1 & 3.33 & 0 & 0 & 0 & 0 \\
\hline Total & 30.00 & 100.00 & 30.00 & 100.00 & 30.00 & 100.00 & 30.00 & 100.00 \\
\hline
\end{tabular}

$\mathrm{ND}=$ Non detectable level. 
Table 6: Frequency distribution of the examined meat products based on their sorbic acid salts levels ( $n=30$ of each)

\begin{tabular}{|l|c|c|c|c|c|c|c|c|}
\hline \multirow{2}{*}{$\begin{array}{c}\text { Levels } \\
\text { range }\end{array}$} & \multicolumn{2}{|c|}{ Sausage } & \multicolumn{2}{c|}{ Pastrami } & \multicolumn{2}{c|}{ Corned beef } & \multicolumn{2}{c|}{$\begin{array}{c}\text { Canned luncheon } \\
\text { beef }\end{array}$} \\
\cline { 2 - 9 } & No. & $\%$ & No. & $\%$ & No. & $\%$ & No. & $\%$ \\
\hline 0 (ND) & 0 & 0 & 0 & 0 & 30 & 100.00 & 30 & 100.00 \\
\hline$>0-0.5$ & 7 & 23.33 & 3 & 10.00 & 0 & 0 & 0 & 0 \\
\hline$>0.5-1.0$ & 9 & 30.00 & 10 & 33.33 & 0 & 0 & 0 & 0 \\
\hline$>1.0-1.5$ & 10 & 33.33 & 6 & 20.00 & 0 & 0 & 0 & 0 \\
\hline$>1.5-2$ & 2 & 6.67 & 6 & 20.00 & 0 & 0 & 0 & 0 \\
\hline$>2-2.5$ & 2 & 6.67 & 5 & 16.67 & 0 & 0 & 0 & 0 \\
\hline Total & 30.00 & 100.00 & 30.00 & 100.00 & 30.00 & 100.00 & 30.00 & 100.00 \\
\hline
\end{tabular}

$\mathrm{ND}=$ Non detectable level.

Table 7: Correlation between the different mean values of nitrite, nitrate and sorbic acid salts levels in the examined meat products samples (at $\mathrm{p}=0.05$ "95\%" and $\mathrm{p}=0.01$ "99\%").

\begin{tabular}{|c|c|c|c|}
\hline & Nitrite & Nitrate & Sorbic acid salts \\
\hline Nitrite & ---------------- & $0.023(*)$ & $0.000(* *)$ \\
\hline Nitrate & $0.023(*)$ & -----------. & 0.055 \\
\hline Sorbic acid salts & $0.000(* *)$ & 0.055 & ---- \\
\hline
\end{tabular}

$(* *)=$ Highly significant relationship at $0.01(99 \%)$.

$(*)=$ Significant relationship at $0.05(95 \%)$. 
Table 8: Comparison between the mean values of nitrite, nitrate and sorbic acid salts with the permissible limits of each in the examined meat products.

\begin{tabular}{|c|c|c|c|c|c|c|c|c|c|c|c|c|c|c|c|}
\hline \multirow{4}{*}{$\begin{array}{c}\text { Meat } \\
\text { products }\end{array}$} & \multicolumn{5}{|c|}{ Nitrite } & \multicolumn{5}{|c|}{ Nitrate } & \multicolumn{5}{|c|}{ Sorbic acid salts } \\
\hline & \multicolumn{4}{|c|}{ Results } & \multirow{2}{*}{ 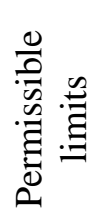 } & \multicolumn{4}{|c|}{ Results } & \multirow{2}{*}{ 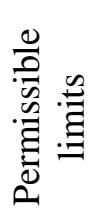 } & \multicolumn{4}{|c|}{ Results } & \multirow{2}{*}{ 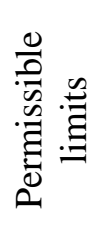 } \\
\hline & \multicolumn{2}{|c|}{ Allowed } & \multicolumn{2}{|c|}{$\begin{array}{c}\text { Not } \\
\text { allowed }\end{array}$} & & \multicolumn{2}{|c|}{ Allowed } & \multicolumn{2}{|c|}{$\begin{array}{c}\text { Not } \\
\text { allowed }\end{array}$} & & \multicolumn{2}{|c|}{ Allowed } & \multicolumn{2}{|c|}{$\begin{array}{c}\text { Not } \\
\text { allowed }\end{array}$} & \\
\hline & No. & $\%$ & No. & $\%$ & \multirow{5}{*}{ 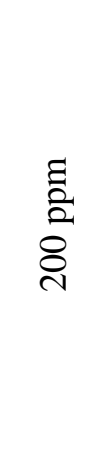 } & No. & $\%$ & No. & $\%$ & \multirow{5}{*}{ 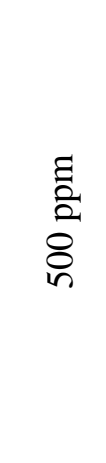 } & No. & $\%$ & No. & $\%$ & \multirow{5}{*}{$\begin{array}{l}\text { in } \\
\text { bo } \\
\stackrel{0}{0} \\
\text { i }\end{array}$} \\
\hline Sausage & 30 & 100 & 0 & 0 & & 30 & 100 & 0 & 0 & & 28 & 93.33 & 2 & 6.67 & \\
\hline Pastrami & 27 & 90 & 3 & 10 & & 30 & 100 & 0 & 0 & & 25 & 83.33 & 5 & 16.67 & \\
\hline $\begin{array}{l}\text { Corned } \\
\text { beef }\end{array}$ & 23 & 76.67 & 7 & 23.33 & & 30 & 100 & 0 & 0 & & 30 & 100 & 0 & 0 & \\
\hline $\begin{array}{l}\text { Canned } \\
\text { luncheon } \\
\text { beef }\end{array}$ & 26 & 86.67 & 4 & 13.33 & & 30 & 100 & 0 & 0 & & 30 & 100 & 0 & 0 & \\
\hline
\end{tabular}


Fig. (1): The mean levels of nitrite, ntrate and sorbic acid salts in some meat products

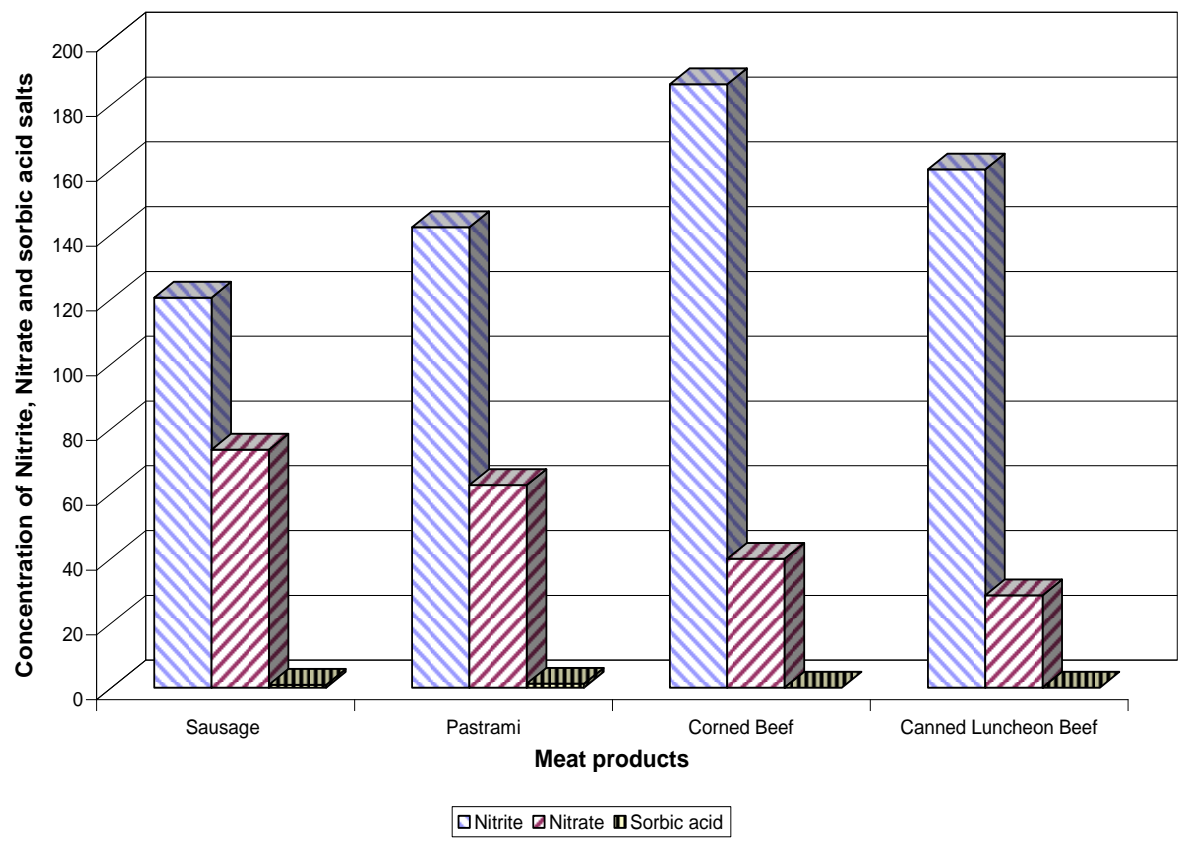

\section{DISCUSSION}

The importance of the various preservatives, which added to meat products during processing are to extend the shelf life and enhanced food safety. They have always been a health safety issues to consumers. Thus, their determination is essential for legislative purpose and consumer's health (Capillas and Colmenero, 2008).

The obtained results in Tables 1-3 and Fig. 1 showed that the mean values of nitrite and nitrate levels in the examined meat products were $120.40 \pm 7.03,142.15 \pm 9.13,186.27 \pm 4.42$ and $159.96 \pm 6.73$ and $73.49 \pm 6.46,62.54 \pm 19.44,39.82 \pm 9.96$ and $28.52 \pm 10.86 \mathrm{ppm}$ for sausage, pastrami, corned beef and canned luncheon beef respectively, while that of sorbic acid salts were $0.92 \pm 0.11,1.25 \pm 0.12,0.00$ and $0.00 \mathrm{~g} / \mathrm{kg}$ respectively. These results were lower or approximately agree with the nitrite level results recorded by Vlascici et al. (2006), but higher than that reported by Babji et al. (1984); Sen and Baddoo (1997); Hamano et al. (1998); Olmos et al. (1998). In case of sorbic acid salts, our results were higher than that recorded by Kim et al. (1986) Song (1995); Do and Cho (2001). The variation between our results and the 
results of other authors may be attributed to the variation in the concentration of the preservative added to the raw meat during meat processing (Mirvish et al., 1995), the difference between the nitrite content of raw meat before processing (JECFA "FAO/WHO", 1974), and the variation in the content of ascorbic acid added to the meat products whereas adding $500 \mathrm{ppm}$ sodium ascorbate decrease the nitrite residue in the meat products (Zhukova, 1999).

Regarding the frequency distribution of the examined meat products samples presented in Tables 4-6, it is evident that nitrite was detected in $100 \%$ of the examined samples, while nitrate was detected in $100 \%, 3.33 \%, 43.33 \%$ and $26.67 \%$ of the examined sausage, pastrami, corned beef and canned luncheon beef respectively. On the other hand sorbic acid salts was detected in $100 \%$ of sausage and pastrami samples only.

In addition, Tables 4-6 showed that most of the examined sausage (100\%), pastrami (90\%), corned beef $(76.67 \%)$ and canned luncheon beef $(86.66 \%)$ had nitrite levels ranged from $>50-200 \mathrm{ppm}$, while $100 \%$, $20 \%, 43.33 \% 23.33 \%$ of the examined sausage, pastrami, corned beef and canned luncheon beef respectively had nitrate levels ranged from $>0-200 \mathrm{ppm}$. The most of sorbic acid salts levels ranged from $>0-2 \mathrm{~g} / \mathrm{kg}$ with a percentage of $93.33 \%$ and $83.33 \%$ for sausage and pastrami samples respectively. The non-detected levels of nitrate were found in samples of pastrami, corned beef and canned luncheon beef in a percentage of $66.67,56.67$ and 73.33 respectively, meanwhile that of sorbic acid salts were $100 \%$ for each of corned beef and canned luncheon beef. The recorded high incidence of nitrite, nitrate and sorbic acid salts in the examined meat product samples than that of other authors may be attributed to the ability, rate and amount of the conversion of nitrate to nitrite (Shemshadi et al., 2006), high amount of preservative added (Mirvish et al., 1995), high levels of nitrite in raw meat (JECFA "FAO/WHO", 1974), and low amount of ascorbic acid added to the meat (Zhukova, 1999).

Statistically by using One-Way ANOVA test to compare the means values of the nitrite, nitrate and sorbic acid salts in the examined meat products samples (Table 7), showed a significant relationship between the mean values of nitrite and nitrate but a highly significance relationship between the mean values of nitrite and sorbic acid salts. The relation between Nitrate and sorbic acid salts was non-significance. This indicates that nitrite and nitrate levels related to each other during the meat processing according to Lundberg et al. (2004). 
In comparison with the permissible limits of the nitrite, nitrate and sorbic acid salts in the examined meat products samples, Table 8 showed that $10 \%$ (3), $23.33 \%$ (7) and $13.33 \%$ (4) of pastrami, corned beef and canned luncheon beef samples exceeded the permissible limits of nitrite established by JECFA "FAO/WHO" (1974 and 2005) respectively, while nitrate not exceed the permissible limits. In case of sorbic acid salts, $6.67 \%$ (2) of sausage and $16.67 \%$ (5) of pastrami were exceeding the permissible limits of sorbic acid salts. The recorded high permissible limits in a few of the examined meat products samples may be regarded to an error in the processing of these meat products samples concerning the extension of the shelf life is the more important aim for economic income than the adverse effect of the used preservative on consumer's health, although cured meat color can be obtained with 50 ppm nitrite or $100 \mathrm{ppm}$ nitrate in the cure mixture (Zaika et al., 1976).

Concerning the toxic effect of the preservatives exposure and the high consumption of meat products by large majority of people (Walker, 1990; Kalalou et al., 2004; Jakszyn and Gonzalez, 2006), the overcome of these hazardous effects with the elongation of the shelf life and maintenance of the quality of the meat products are the main goal. Thus, in conclusion, we implemented to reduce the use of preservatives with the maintenance of their benefits action. The addition of nitrite should be limit to a few special food products where Clostridium botulinum really represents a hazardous to human health e.g. canned meat; some cure meat and fermented products, this mean nitrite should be permitted only for meat products were it exerts a clear beneficial function. Nitrite should not be used for products that have been traditionally manufactured without them e.g. that cooking by final consumers or the preparation of minced meat. Nitrosamine inhibiting agents as ascorbate, alpha tocopherol or both during the processing of meat products should be added to reduce the hazardous effects. Periodic monitoring of nitrite, nitrate and nitrosamine in the meat products in the plant before marketing and in the market should be permitted as a role of the authorities for local and imported meat products. A combination of a lower level of potassium sorbate with sodium nitrite should be used to reduce the nitrosamine formation, provide a safe antibotulinal and long shelf life of the products depending up on their synergistic action. Strict law enforcement should be under taken by the authorities and the modern food technologist regarding a control on the different sources of nitrite contaminants for food animals and environment (Nitrite free raw meat). 


\section{REFERENCES}

AMI "American Meat Institute" (1978): Nitrite, American Meat Institute. P.O. Box 3556 Washington D.C. 20007.

A.O.A.C. (2000): Association of Official Analytical Chemists. $17^{\text {th }}$ ed. Published by O.M.A. Washington, D.C., U.S.A. Chap. 39-47.

Babji, A.S.; Aishah, H. and Aminah, A. (1984): Nitrite content of some Foods Malaysia. Pertanika 7 (2): 39-41

Capillas, R.C. and Colmenero, J.F. (2008): Determination of preservatives in meat products by flow injection analysis (FIA). Food Addit. Contam. Part A Chem. Anal Control Expo Risk Assess., 25 (10): 1167-1178.

Chan, T.Y. (1996): Food-borne nitrates and nitrites as a cause of methemoglobinemia. Southeast Asian J. Trop. Med. Public Health, 27: 189-192.

Dahle, H.K. (1979): Nitrite as a food additive. NIPH ANN., 2 (2): 17-24.

Davidson, P.M. and Juneja, V.K. (1990): Antimicrobial agents. In Food Additives, edited by A.L. Branen, P.M. Davidson and S. Salminen, Marcel Dekker, Inc., New York. p. 83-137.

Do, J.C. and Cho, J.S. (2001): Survey on the sorbic acid concentration in cooked meat produced from meat processing plants. Kor. J. Vet. Serv. 14 (4): 353-358.

Ferrand, C.; Mark, F.; Fritsch, P.; Cassand, P. and De Saint Blanquat, G. $(2000 \mathrm{a})$ : Mutagenicity and genotoxicity of sorbic acidamine reaction products. Toxicol. In Vitro, 14: 423-428.

Ferrand, C.; Mark, F.; Fritsch, P.; Cassand, P. and De Saint Blanquat, $G$. $(2000 \mathrm{~b})$ : Genotoxicity study of reaction products of sorbic acid. J. Agric. Food Chem., 48: 3605-3610.

FAO "Food and Agriculture Organization" (1986): Food Additive methods- Preservative. Sorbic acid. Manual of Food Quality Control. 7. Food Analysis: General analysis: general technique, additives, contaminants, and composition. Food and Agriculture Organization of the United Nation, Rome, Italy, Chap. 5, pp. 60-61.

FDA "Food and Drug Administration" (1998): Heading off Migraine Pain. FDA Consumer Magazine.

Garcia, T.; Martin, R.; Sanz, B. and Hernandez, P. (1995): "Extensión de la vida útil de la carne fresca, In: Envasado en atmósfera modificadas y utilización de bacterias lácticas y bacteriocins". Rev. Espanõla de Cienc. Tecnol. AL., 35: 1-18. 
Gosselin, R.E.; Smith, R.P. and Hodge, H.C. (1984): Clinical Toxicology of Commercial Products. $5^{\text {th }}$ ed. Williams and Wilkins III- 314-319.

Grosse, Y.; Baan, R.; Straif, K.; Secretan, B.; El Ghissassi, F. and Cogliano, V. (2006): Carcinogenicity of nitrate, nitrite and cyanobacterial peptide toxins. Lancet Oncol, 7: 628-629.

Hamano, T.; Mitsuhashi, Y.; Aoki, N.; Semma, M.; Ito, Y. and Oji, Y. (1998): Enzyme method for determination of nitrite in meat and fish products. Analyst. Vol. 123 (1127-1129).

Henderson, W.R. and Raskins, N.H. (1972): Hot dog headaches: Individual susceptibility to nitrite. Lancet, 2 (7788): 1162-1163.

Honikel, K.O. (2008): Symposium on Meat Safety: from Abattoir to Consumers. Meat Science, 78 (1-2): 68-76.

Howe, G.R.; Harrison, L. and Jain, M. (1986): A short diet history for assessing dietary exposure to $\mathrm{N}$-nitrosamines in epidemiologic studies. Am. J. Epidemiol. 124: 595-602.

Hyytia, E.; Eerola, S.; Hielm, S. and Korkeala, H. (1997): Sodium nitrite and potassium nitrate in control of nonproteolytic Clostridium botulinum outgrowth and toxigenesis in vacuum packed cold smoked rainbow trout. International Journal of Food Microbiology, 37: 63-72.

I.S.O. (1975): International Organization for Standardization. Methods of Test 2918. Meat and Meat Products. Determination of Nitrite content.

Jakszyn, P. and Gonzalez, C.A. (2006): Nitrosamine and related food intake and gastric and esophageal cancer risk a systematic review of the epidemiological evidence. World $\mathrm{J}$. Gastroenterol., 12: 4296-4303.

JECFA (FAO/WHO) (1974): Seventeenth report of Joint FAO/WHO Expert Committee on Food Additives, World Health Org. Tech Rep. Ser. No. 539.

JECFA (FAO/WHO) (2005): Joint Expert Committee on Food Additives, Food additive series 50; sodium nitrite CAS No.: 7632-00-0 OECD SIDS, Initial Assessment report for SIAM 20; Paris, France, 19-22 April 2005

Kalalou, I.; Faid, M. and Ahami, A. (2004): Extending shelf life of fresh minced camel meat at ambient temperature by Lactobacillus delbrueckii subspecies delbrueckii. Electronic Journal of Biotechnology vol. 7 No. 3. 
Kim, K.S.; Lee, C.W. and Lee, T.S. et al., (1986): Survey on intakes of food additives by Koreans (II). Reporter of NIH Korea 23: 631-642.

Lijinsky, W. and Kovatch, R.M. (1982): Carcinogenesis by nitrosamines and azoxyalkanes by different routes of administration to rats. Biomed. Env. Science, 2: 154-159.

Lindsay, R.C. (1985): Food Additives. $2^{\text {nd }}$ ed. Food Chemistry. In: Fennema, O.R. (ed.), Marcel Dekker, inc., New York, pp. 629-688.

Lindsay, R.C. (1996): Food Additives. $4^{\text {th }}$ ed. Food Chemistry. In: Fennema, O.R. (ed.). Marcel Dekker, inc., New York, pp. 767-824.

Lundberg, J.O.; Weitzberg, E.; Cole, J.A. and Benjamin, N. (2004): Nitrite, bacteria and human health. Nat. Rev. Microbiol.

Mihyar, G.F.; Yousif, A.K. and Yamani, M.I. (1999): Determination of benzoic and sorbic acids in labaneh by high performance liquid chromatography. Journal of Food Composition and Analysis, 12: 53-61.

Miller, A.B. (1985): Diet, nutrition and cancer. J. Nutr. Growth Cancer, 2: $159-171$.

Mirvish, S.S. (1995): Role of N-nitroso compounds (NOC) and $\mathrm{N}$-nitrosation in etiology of gastric, esophageal nasopharyngeal and bladder cancer and contribution to cancer of known exposures to NOC. Cancer Lett. 93: 17-48.

Mirvish, S.S.; Grandjean, A.C.; Reimers, K.J.; Connelly, B.J.; Chen, S.; Gallagher, J.; Rosinsky, S.; Nie, G.; Tuatoo, H.; Payne, S.; Hinman, C. and Ruby, E.I. (1995): Dosing time with ascorbic acid and nitrite, gum and tobacco chewing, fasting and other factors affecting $N$-nitrosoproline formation in healthy subject taking proline with a standard meal. Cancer Epidem. Biomark. Prevention 4: 775

Mota, F.J.M.; Ferreira, I.M.P.; Cunha, S.C.; Beatriz, M. and Oliveira, P.P. (2003): Optimisation of extraction procedures for analysis of benzoic and sorbic acids in foodstuffs. Food Chemistry, 82: 469-473.

Narayana, B. and Sunil, K. (2009): A Spectrophotometric method for determination of nitrite and nitrate. Eurasian J. Chem. 4 (2): 204-214.

Nijinsky, W. (1999): N-Nitroso compounds in the diet. Mutat. Res., 443: 129-138. 
Noel, P.; Briand, E. and Dumont, J.P. (1990): Role of nitrite in flavour development in uncooked cured meat products: sensory assessment. Meat Science, 28: 1-8.

Olmos, R.P.; Yoldi, I.; Ruz, M.P. and Merino, J.M. (1998): Potentiometric determination of nitrite in meat products using a Nitrite-selective electrode. Analytical Science Vol. 14: pp 1001-1003.

Olsman, W.J. (1977): Proceeding of the Second International Symposium in Nitrite on Meat Products; Tinbergen, B. J.; Krol, B., Eds.; Wageningen: PUDOC, 101-110.

Roberts, T.A. and Ingram, M.C. (1977): Proceeding of the Second International Symposium in Nitrite on Meat Products; Tinbergen, B. J.; Krol, B., eds.; Wageningen: PUDOC, 29-38.

Saad, B.; Bari, M.F.; Saleh, M.I.; Ahmad, K. and Talib, M.K.M. (2005): Simultaneous determination of preservatives (benzoic acid, sorbic acid, methylparaben and propylparaben) in foodstuffs using high performance liquid chromatography. Journal of Chromatography A, 1073: 393-397.

Safford, R.J.; Basketter, D.A.; Allenby, C.F. and Goodwin, B.F.J. (1990): Immediate contact reactions to chemicals in the fragrance mix and a study of the quenching action of eugenol. British J. Dermatol., 123: 595-606.

Sen, N.P. and Baddoo, P.A. (1997): Trends in the levels of residual nitrite in Canadian cured meat products over the past 25 years. J. Agric. Food Chem., 45(12): 4714-4718.

Shahidi, F.; Rubin, L.J. and Wood, D.F. (1988): Stabilization of meat lipids with nitrite-free curing mixture. Meat Science, 22: 73-80.

Shapiro, K.B.; Hotchkiss, J.H. and Roe, D.A. (1991): Quantitative relationship between oral nitrate-reducing activity and the endogenous formation of $\mathrm{N}$-nitrosoamino acids in humans. Food Chem. Toxicol. 29: 751-755.

Shemshadi, B.; Hosseini, H. and Ferdosy, R. (2006): Preservative residue in beef and chicken sausages and bolognas marketed in Iran. IUFoST, $13^{\text {th }}$ World Congress of Food Science and Technology. Food is Life, 17-21 September 2006. Nantes France. www.inra.fr/iufost2006

Sofos, J.N. and Busta, F.F. (1993): Sorbic acid and sorbates. In Antimicrobials in Foods, $2^{\text {nd }}$ ed.; Davidson, P. M., Branen, A. L., Eds.; Marce Dekker, Inc.; Ne York, pp. 49-94. 
Song, M.R. (1995): Analysis of sorbic acid contents in processed meat products consumed in Korea (II). Ki-jun Lady Junior College: 242-243.

Twombly, R. (1995): What's eating us, about what we're eating. Env. Health Persp. 103: 556-559.

Vlascici, D.; Pica, E.M.; Cosma, E.F.; Bizerea, O. and Cosma, V. (2006): Determination of nitrite in meat products using a metalloporphyrin based nitrite-selective membrane electrode. Leonardo Electronic Journal of Practices and Technologies Vol. 9, Pp. 5-16.

Walker, R. (1990): Toxicology of sorbic acid and sorbates. Food Addit. Contam., 7: 671-676.

Zaika, L.A.; Zell, T.E.; Smith, T.L.; Palumbo, S.A. and Kissinger, J.C. (1976): The role of nitrite and nitrate in Lebanon Bologna, a fermented sausage. J. Food Sci. 41: 1457-1460.

Zhukova, G.F. (1999): N-Nitrosamine and nitrites in meat and foodstuffs. Voprosypitania: 68 (4): 32-34. 
Assiut Vet. Med. J. Vol. 57 No. 129 April 2011 